\title{
The Ability of Gymnastics Motoric Perceptual Based on Local Culture for Early Childhood in Aceh Province
}

\author{
Muhammad Riski Kurniawan ${ }^{1}$, Syamsulrizal $^{2}$, Razali $^{2}$, Israwati ${ }^{2}$ \\ ${ }^{1}$ Masters in Physical Education, Universitas Syiah Kuala, Banda Aceh, Indonesia \\ ${ }^{2}$ Faculty of Teacher Training and Education, Universitas Syiah Kuala, Banda Aceh, Indonesia \\ mriskikurniawan.mpo17@edu.unsyiah.ac.id
}

\begin{abstract}
Local culture-based gymnastics is a combination of Seudati dance with Saman dances movements as well as cheerful healthy exercises that are already in kindergarten. The purpose of this study was to determine the impact of the implementation of local culture-based exercise on the motorized perceptual ability of early childhood in Banda Aceh Kindergarten. This study uses a quantitative approach to the type of experimental research. Population and a sample of 30 students were selected by purposive sampling. Data collection techniques of motoric perceptual ability using tests: (1) Standing on the beam while touching the limbs as instructed by the teacher with eyes open, $(2$ ) Standing on the beam while touching the body as instructed by the teacher with eyes closed, (3) Jumping and landing in a line with two feet pressed together as instructed by the teacher with eyes open, (4) Jumping and landing in a line with two feet pressed together as instructed by the teacher with eyes closed, (5) Walking in balance, (6) Throwing a tennis ball into a basket with a distance of 2 meters. Before the data is analyzed, the research data is tested for the analysis requirements, namely the normality and homogeneity test. Then the data is analyzed using the t-test. Based on the results of data analysis obtained t count (18.455)> $t$ table (2.045), thus it can be concluded that there is a significant influence between local culture-based exercise on the motoric perceptual ability of early childhood in Aceh kindergarten.
\end{abstract}

Keywords

healthy gymnastics; culturebased; motoric perceptual; early childhood

\section{Introduction}

Early childhood education (PAUD) is a form of education that focuses on laying the foundation for physical growth and development (fine and gross motoric coordination), intelligence (thinking power, creativity, emotional intelligence, spiritual intelligence), social emotional (attitude and behavior as well as religion), language and communication, according to the uniqueness and stages of development that are passed by early childhood.

Amelia (2020) states early childhood is a community that is vulnerable to becoming victims when natural disasters occur. According Law Number 20 of 2003, Early Childhood Education (PAUD) is a coaching effort aimed at children from birth to the age of six years which is carried out through providing educational stimuli to help physical and spiritual growth and development so that children have readiness to enter further education.

Specifically in physical learning, sports and health in kindergarten aims to increase physical potential and instill sportsmanship and awareness of healthy and clean living, (Ministry of National Education, 2010: 9-10). In accordance with the curriculum in kindergarten, that physical or physical activity is the scope of physical, sports, and health 
learning programs in the form of physical activities that contain motor perceptual elements and are packaged in the form of measurement tests. According to Ananda (2019) every teaching and learning process must be carried out in the evaluation activities, to see how the progress that has been achieved by students and how effective the teaching is done by the teacher in the class. Measurement of motor perceptual ability from the beginning, especially in kindergarten children is very important to be done to determine the children's motor perceptual ability at the kindergarten level.

This study wants to examine the children's motoric ability developed through gymnastics activities originating from the Aceh region, under the name of local culture-based Gymnastics. This needs to be implemented to assess the suitability of the movement with the child's motoric ability and also to introduce local cultural values to children from an early age in the Banda Aceh city area. Rahmah (2019) states traditional art as one of the material that must be studied, so far has been taught only by oral tradition, focusing on dance.

Local Culture Based Gymnastics is a combination of Seudati dance with Saman dances and kindergarten exercises movements. The combination of these movements was accompanied by poems in the Acehnese language, which were taken from the song Saleum, Meusare-sare and the Aceh Loen Sayang song. Aceh's art basically has a real characteristic, namely there is an Islamic cultural content in it.

Based on the results of preliminary observations in Banda Aceh Kindergarten that the child's motoric perceptual abilities seem to be still low or not yet developed optimally. This can be seen from the low movement in the place (non-locomotor) and movement (locomotor), so that children in play activities have not been able to use tools or learning media both in gross motoric and fine motoric children. Other observations when the child morning exercise activities, there are still children who are less active in following the gymnastic movements, some children seem to be more quiet without doing movements. It can be seen that the child's motoric ability are not well trained so that the child's muscles are less moving and his motoric ability are less developed.

In this study, local culture-based gymnastics activities were chosen through regional movements and songs in the hope that the emergence of young people who loved their culture and were actually carried out in their daily lives and had an impact on the social life of their communities. Many of the concepts of special education in early childhood offered by government and non-government institutions from abroad that are not rooted in local culture, so that it will be bad for the character of children in the city of Banda Aceh in the future (Razali, 2019).

The song that is accompanied by following local cultural-based gymnastics, if actively played to the child while playing with joy, this is the stage of introducing the child without coercion and influencing the child's motoric relationships. Through local culture-based gymnastics, can hone the perceptual motoric ability of early childhood to develop optimally and benefit the health of kindergarten children in Aceh.

\section{Review of Literature}

\subsection{Definition of Implementation}

According to Hamalik (2007: 237) "implementation is a process of applying ideas, concepts, policies, or innovations in the form of practical actions so as to have an impact, whether in the form of changes in knowledge, skills, as well as values and attitudes". Implementation is usually done after planning is considered fixed. Implementation can also mean an implementation derived from the English word Implement which means to 
implement. While the opinion of Usman (2002: 70) "implementation is leading to the activities, actions, actions or mechanisms of a system, implementation is not just an activity, but a planned activity and to achieve the objectives of the activity".

Based on the opinion of the experts above, it can be concluded that implementation is an application or action taken based on a plan that has been prepared or made carefully and in detail in advance. These activities can be carried out by the government, individuals, groups, or other parties. So in this study the researchers wanted to implement a form of local culturalbased gymnastics movements to students of Aceh kindergarten.

\subsection{The Essence of Gymnastics}

Gymnastics movements must always be useful to have certain goals such as: increase flexibility, improve attitude and movement or beauty of the body, increase skills, and enhance the beauty of the body and movements must always be arranged and systematic. According to Margono (2009: 19), the definition of gymnastics is a body exercise that is chosen and created in a planned manner, arranged systematically with the aim of forming and developing a harmonious personality.

Gymnastics also has the potential to develop basic movement skills, as an important foundation for the masters of the technical skills of a sport. Now, since childhood many children are accustomed to being taught gymnastics, both by parents, and by sports instructors at school (Kinanti, 2004: 34). Gymnastics can be achieved if gymnastics are done regularly, continually and programmed, so that it can support the establishment of physical fitness elements. Exercise exercises that are done well and regularly can make the body become stronger, attitude and stature (posture) for the better.

\subsection{Local Culture Based Gymnastics}

Gymnastics based on local Acehnese culture where there are types of physical exercise, arranged and arranged systematically combined with the rhythm of Acehnese cultural music, the aim is to activate the brain and improve flexibility, mental attitude, health and physical fitness of children. Local culture-based gymnastics is the development of smart, cheerful, healthy cheerful gymnastics and Acehnese cultural dances and uses Acehnese regional songs to accompany the movement in local culture-based gymnastics. Songs used for local culturebased gymnastics are: Saleum songs, Meusare-sare songs, and Aceh Loen Sayang songs.

In Acehnese local culture-based gymnastics the movements in gymnastics have been validated by experts. In this exercise can optimize physical and motoric development so that the physical development of children from an early age will be more optimal growth and cognitive development of children. The form of the movements and the attitude of the exercise are more colored by the regional dance movements of Aceh. For example, movements of curved body movements, finger picking, back and forth, arms crossed, reaching for something above the head and sides of the body, waving both arms while swinging, shrinking and widening the body, running, jumping crossed legs, jumping at the core is the imagination of the child's movements play, then the forms of movement are combined by considering the aesthetic value and beauty of each movement into one series

Thus the nuances of Acehnese culture and children playing, more pronounced in this exercise, the characteristics of children who are playing are expressed in nuances that are dynamic, cheerful and uplifting. In local culture-based gymnastics consists of 3 forms of exercise provided consisting of (1) warming up to 7 movements whose duration is 1 minute 14 seconds. (2) A total of 26 movements whose duration is 4 minutes. (3) Cooling consists of 12 movements whose duration is 2 minutes with slower movements in order to decrease the 
activity that has been taking place gradually. Each session between the heating, core and cooling movements is given a pause of 3 seconds.

\subsection{The Nature of Motoric Perceptual}

Motoric perceptual basically refers to activities carried out with the intention of improving cognitive and academic abilities. Perceptual activity is basically the process of introducing children to their environment. According to Sugiyanto, (2007: 85) states that motoric perceptual is the ability to interpret the stimulus received by the sense organs. Perceptual ability is useful to understand everything around, so that someone is able to do or do certain actions in accordance with the situation at hand.

Motoric perceptual consists of various elements, including: body awareness, space awareness, direction awareness and tempo awareness, (Rusli Lutan: 2001: 8). The following is an explanation of various motoric perceptual elements:

a. Awareness of the body's ability to know and understand the names and functions of various body parts.

b. Space awareness, such as walking on beams, meandering, climbing stairs is a movement that is related to the ability of the reaction, in harmony with stimuli and the surrounding environment.

c. Awareness of the direction of the ability to understand and apply the concept of direction, such as up and down, forwards and backwards, left and right.

d. Temporal awareness is a coordinating movement between the eyes and limbs to be more efficient.

The process of motoric perceptual occurrence goes through several stages, which include: the inclusion of stimuli through sensory nerves, the combination of excitement, interpretation of motion, activation of motion, and feedback. The process of motoric perceptual occurrence can be described in the following figure:

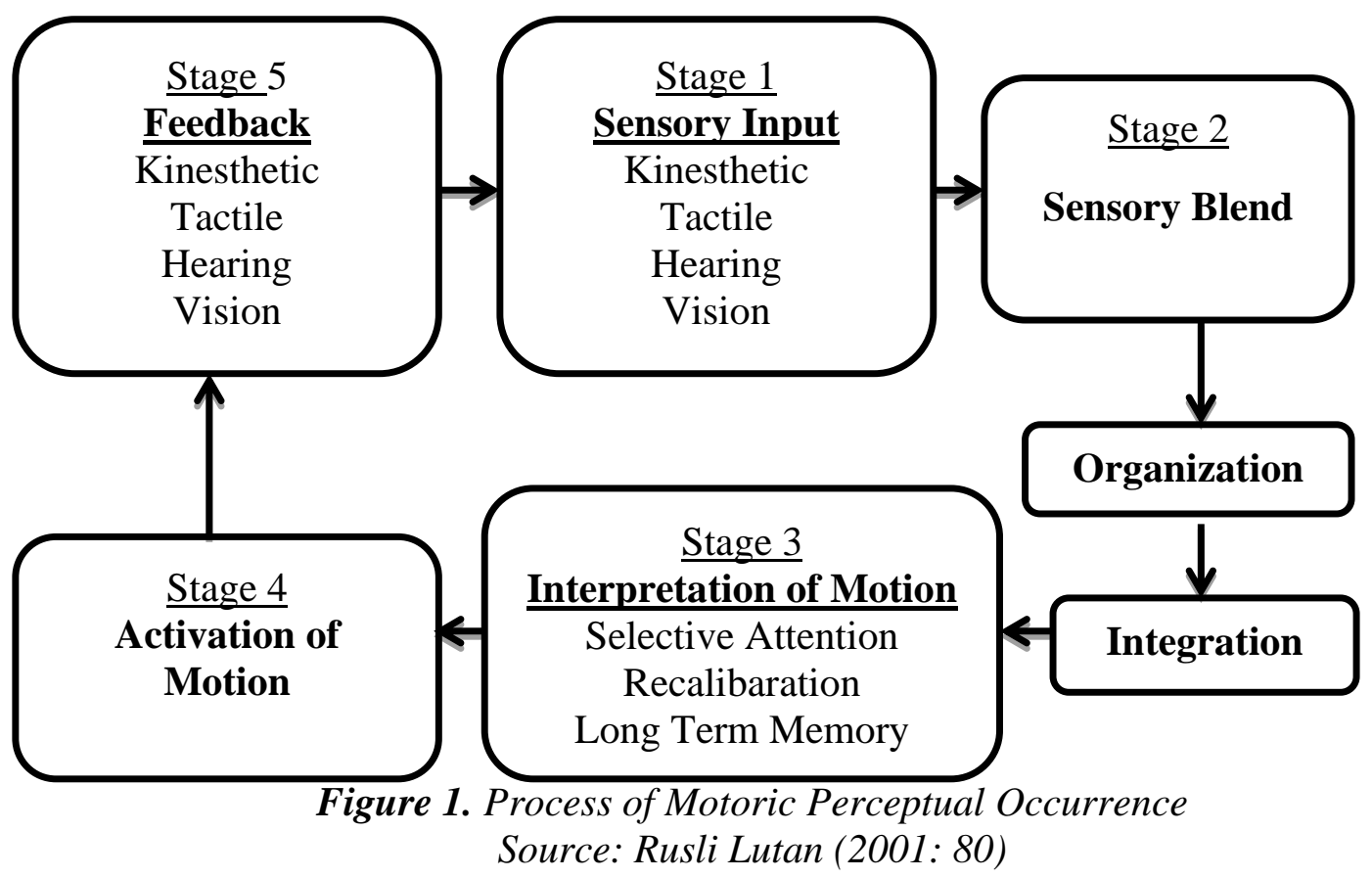

From the figure above can be explained about the process of motoric perceptual occurrence, as follows: 
a. Stimulation input through sensory nerves: various stimuli that have been captured through sensory nerves, such as: vision, hearing, touch, and kinesthetic.

b. Combination of stimuli: stimuli that have been obtained are then combined or stored together with stimuli that have been obtained and stored in memory.

c. Interpretation of motion: based on the understanding of excitement that has been received, then the pattern of motion will be decided.

d. Activation of motion: at this stage is the actual occurrence of motion carried out and this motion can be observed.

e. Feedback: at this stage it is an evaluation of the motion carried out through various sensory devices, which is then the feedback information, passed on to several sources of information input, such as: from observation or feeling. The next stage is the implementation of the motion in accordance with the correction obtained.

Perceptual motoric is formed by two systems, namely: (1) perception system and (2) sensory system. The two aspects cannot be separated, because we cannot possibly issue a perception without making observations through sensing. Saputra (2003: 22) argues that perceptual motion is the relationship between motion and perception. Perception is the process of receiving, selecting, and understanding information or stimuli from the outside. Perception produces awareness about what is happening outside us.

The Nature of Early Childhood

Early childhood has unique characteristics, both physically, socially, morally and so on. According to Siti Aisyah, et al (2010: 1.4-1.9) characteristics of early childhood, among others; a) has a great curiosity, b) is a unique person, c) likes to fantasize and imagine, d) the most potential time to learn, e) shows an egocentric attitude, f) has a short span of concentration power, g) as part from social beings. Characteristics of preschooler development can be described in several ways, namely: physical development, motoric development, cognitive development, and social-emotional development.

According to Bambang Sujiono, (2007: 1.15-1.16) gross and fine motoric development in kindergarten students include:

Table 1. Motoric Development in Children Aged 3-4 Years

\begin{tabular}{|l|l|}
\hline \multicolumn{1}{|c|}{ Rough Motoric } & \multicolumn{1}{c|}{ Soft Motoric } \\
\hline 1. Catch a big ball by hand. & 1. Cut the paper into two parts. \\
\hline 2. Stand on one leg for 5 seconds. & 2. Wash and wipe your own hands. \\
\hline $\begin{array}{l}\text { 3. Ride a tricycle through wide bends. } \\
\text { 4. Jumping 1 meter or more from its } \\
\text { original position. }\end{array}$ & 3. Stir the liquid with a spoon. \\
\hline $\begin{array}{l}\text { 5. Take a small object on the tray } \\
\text { without dropping it. }\end{array}$ & 5. Hour water from the teapot. \\
\hline $\begin{array}{l}\text { 6. Use the shoulders and elbows when } \\
\text { throwing the ball up to 3 M. }\end{array}$ & 6. Bring something with a brace. \\
\hline $\begin{array}{l}\text { 7. Walk down the board by placing one } \\
\text { foot in front of the other. }\end{array}$ & 7. If an incomplete picture of the human \\
body's head is given, it will be able to \\
add at least two organs.
\end{tabular}

Table 2. Motoric Development of Children Aged 5-6 Years 


\begin{tabular}{|c|c|}
\hline Rough Motoric & Soft Motoric \\
\hline 1. Run and immediately kick the ball. & 1. Tying shoelaces. \\
\hline 2. Jumping with alternating legs. & 2. Put the letter in the envelope. \\
\hline $\begin{array}{l}\text { 3. Toss a tennis ball with one hand and } \\
\text { catch it with two hands. }\end{array}$ & 3. Smear jam on bread. \\
\hline 4. Walk on a predetermined line. & 4. Form various objects with clay. \\
\hline 5. Tiptoe with hands on hips. & $\begin{array}{l}\text { 5. Wash and dry face without wetting } \\
\text { the clothes. }\end{array}$ \\
\hline $\begin{array}{l}\text { 6. Touch your toes without bending your } \\
\text { knees. }\end{array}$ & 6. Insert thread into the needle. \\
\hline $\begin{array}{l}\text { 7. Pedaling one foot forward or back } \\
\text { without losing balance. }\end{array}$ & \\
\hline
\end{tabular}

\section{Research Methods}

The approach used in this study is a quantitative approach. According to Sugiyono (2011: 14) "quantitative research is a research method used to examine a particular population or sample, data collection using research instruments, data analysis using numbers and are statistical in nature with the aim to test the hypothesis that has been set ". While the type of research that researchers use is experimentation. Sugiyono (2013: 107) said "Experimental research is the existence of treatment, thus the experimental research method can also be interpreted as a research method used to look for the effect of certain treatments on others under controlled conditions".

The research design used in this study is one group pre-test-post-test design. In this study, samples were given a pre-test (pretest) which is a test of motoric perceptual ability. Then given treatment (local culture-based gymnastics) and then to the sample given a final test (post-test) that is a test of motoric perceptual ability to determine the impact of the implementation of local culture-based gymnastics on motoric perceptual ability to use motorized perceptual indicators of early childhood .

This research was conducted in Aceh Kindergarten with the address of Jalan Krueng Tripa Geuceu Komplek Banda Raya District. The time of this research began from September 21, 2019 to November 2, 2019. The population of this study were all kindergarten students of Banda Aceh City, amounting to 138 students. In this study were 30 students in group B aged 5-6 Aceh kindergarten who were taken by using the technique of physics purposive sampling that is with certain criteria.

Some of the tests used to look at the motoric perceptual abilities of kindergarten children in Aceh are:

a. Pre Tests are given to measure the motor's perceptual ability of children who have not been treated in the form of cultural exercises using the following test kits:

1) Stand on the beam (10 cm wide, $20 \mathrm{~cm}$ long, and $5 \mathrm{~cm}$ high) while touching the limbs, according to the teacher's instructions with your eyes open.

2) Stand on the beam (10 cm wide, $20 \mathrm{~cm}$ long and $5 \mathrm{~cm}$ high) while touching the limbs, according to the teacher's instructions with eyes closed.

3) Jumping and landing with two feet pressed together, according to the teacher's orders with eyes open.

4) Jumping and Landing is lined with two feet together, according to the teacher's orders with eyes closed.

5) Walk with a balance of $3 \mathrm{M}$ in length, $10 \mathrm{~cm}$ in width and $20 \mathrm{~cm}$ in height.

6) Throwing the tennis ball to the shell with a distance of 2 meters. 
b. After an initial motoric perceptual ability test was conducted to the Pertiwi Banda Aceh Kindergarten students, in the second stage this was given treatment in the form of local culture-based gymnastics to students for 1.5 months and every week 3 times were given cultural exercise to students. This local culture-based gymnastics lasts 7 minutes 14 seconds by giving exercises to a sample of $16 \mathrm{x}$ meetings with intensity done three times a week.

c. After being given a cultural gymnastics treatment, this stage is carried out a final motorized perceptual ability test (post-test) to see the extent to which students can do the test at the first stage carried out before the local culture-based gymnastics treatment is given to students.

\section{Discussion}

\subsection{Analysis Test Results of Motoric Perceptual Ability}

The following explains the results of the analysis of the motoric perceptual test of early childhood at TK Pertiwi Banda Aceh City from the results of the pre-test, treatment and post-test that have been given to students as follows:

Table 3. Sample characteristics of Pertiwi Kindergarten students in Banda Aceh City

\begin{tabular}{|c|c|c|c|c|c|c|}
\hline Male & $\mathbf{N}$ & Mean & SD & Variance & Minimum & Maximum \\
\hline TS1A & 15 & 28.47 & 9.357 & 87.55 & 16 & 50 \\
\hline TS1B & 15 & 29.40 & 9.694 & 93.97 & 18 & 55 \\
\hline TS1C & 15 & 12.73 & 5.271 & 27.78 & 3 & 20 \\
\hline TS1D & 15 & 10.20 & 5.545 & 30.74 & 3 & 20 \\
\hline TS1E & 15 & 14.47 & 6.334 & 40.12 & 6 & 31 \\
\hline TS1F & 15 & 7.27 & 2.404 & 5.781 & 3 & 12 \\
\hline SKPM1 & 15 & 102.53 & 25.704 & 660.69 & 73 & 174 \\
\hline TS2A & 15 & 43.67 & 12.158 & 147.80 & 20 & 60 \\
\hline TS2B & 15 & 51.60 & 13.389 & 179.25 & 25 & 70 \\
\hline TS2C & 15 & 16.13 & 5.317 & 28.26 & 5 & 24 \\
\hline TS2D & 15 & 13.13 & 4.998 & 24.98 & 6 & 20 \\
\hline TS2E & 15 & 36.27 & 4.773 & 22.78 & 30 & 43 \\
\hline TS2F & 15 & 8.13 & 2.503 & 6.267 & 4 & 12 \\
\hline SKPM2 & 15 & 168.93 & 23.295 & 542.63 & 132 & 206 \\
\hline
\end{tabular}

\begin{tabular}{|c|c|c|c|c|c|c|}
\hline Female & $\mathbf{N}$ & Mean & SD & Variance & Minimum & Maximum \\
\hline TS1A & 15 & 26.47 & 6.116 & 37.41 & 15 & 40 \\
\hline TS1B & 15 & 29.27 & 6.112 & 37.35 & 15 & 38 \\
\hline TS1C & 15 & 13.00 & 5.278 & 27.85 & 3 & 20 \\
\hline TS1D & 15 & 10.07 & 3.105 & 9.638 & 5 & 14 \\
\hline TS1E & 15 & 15.13 & 2.774 & 7.685 & 10 & 20 \\
\hline TS1F & 15 & 5.73 & 2.738 & 7.495 & 2 & 10 \\
\hline SKPM1 & 15 & 99.67 & 12.093 & 146.23 & 79 & 121 \\
\hline TS2A & 15 & 41.13 & 13.298 & 176.83 & 20 & 60 \\
\hline TS2B & 15 & 52.73 & 10.674 & 113.92 & 25 & 65 \\
\hline TS2C & 15 & 16.07 & 4.978 & 24.78 & 8 & 24 \\
\hline TS2D & 15 & 13.13 & 3.603 & 12.78 & 7 & 20 \\
\hline TS2E & 15 & 35.93 & 6.475 & 41.92 & 23 & 43 \\
\hline
\end{tabular}




\begin{tabular}{|c|c|c|c|c|c|c|}
\hline TS2F & 15 & 8.93 & 2.374 & 5.638 & 5 & 12 \\
\hline SKPM2 & 15 & 167.93 & 20.766 & 431.21 & 141 & 199 \\
\hline
\end{tabular}

Source: Research Results

a. Standing on the beam (Length: $20 \mathrm{~cm}$, Width: $10 \mathrm{~cm}$ and height $5 \mathrm{~cm}$ ) while touching the limb, as instructed by the teacher with eyes opened

In the implementation of this test, the average value of participant observation before given local culture-based gymnastics was 27.47, with the lowest score of 15 and the highest score of 50. The average value of boys (28.47) while the average value of average of girls (26.47) where there are fewer boys than girls. After given local culture-based gymnastics treatment, the progress is quite different, because the overall average score is 42.40 . Means an increase in scores from before and after given gymnastic treatment. The lowest value is 20 , but the highest number reaches 60 . An extraordinary progress in achieving this test. The average test score of boys becomes (43.67) while children women become $(41,13)$. The highest scores for boys and girls are 60. In contrast, the lowest scores for boys and girls are 20.

\section{b. Standing on the beam $(10 \mathrm{~cm}$ wide, $20 \mathrm{~cm}$ long and $5 \mathrm{~cm}$ high) while touching the limbs, as instructed by the teacher with eyes closed}

In this second test, the test scores for students before being given local culture-based exercises are not too different from the results of the first test. The average value is generally 29.33, both boys (29.40) and girls (29.27) are not much different. What's interesting is that the highest and lowest scores for girls are lower than the first test (with eyes open), but the average is higher. While for boys it tends to be no different. After given local culture-based exercise training, the second test results obtained a significantly higher average value of 52.17. The average test score of boys becomes (51.60) while girls becomes (52.73). The highest score for boys and girls is the same, namely 60. Conversely, the lowest scores for boys and girls 20. Achievement of the average value in female students is relatively better than male students. Proven on average the value of boys (51.60) is lower than female students (52.73). The highest score is 70 for male and 65 for female. Instead, the lowest score is 24 for male and 25 for girl.

\section{c. Jumping and landing on the line with two feet pressed together, as instructed by the teacher with eyes opened}

In this type of test the achievement value of children tends to be smaller than the previous 2 tests. The overall average recorded is only 12.87, with the lowest value of 3, and the highest value of 20. For boys (12.73) while girls are relatively higher (13). After given local culture-based exercise training, children are relatively more able to practice jumping and landing on the line with two legs close together with eyes open. This is proven by increasing the average value to 16.10 from the previous achievement (12.87) with the lowest value of 5 , and the highest value of 24 . For boys (16.13) while girls are relatively lower (16.07). This was achieved in both boys and girls.

\section{d. Jumping and Landing is lined with two feet pressed together, as instructed by the teacher with eyes closed}

In the practice of this exercise, both boys and girls get relatively the same values. The average score is 10.13. But the highest score (20) while the lowest score is the same, which is 3. After given local cultural-based gymnastics exercises the children's response is much 
better. The average value obtained for this activity becomes 13.13. Both boys and girls experienced significant progress. The lowest score (6) with the highest score (20) is only 5 points apart.

\section{e. Walk on a balance beam with a length of $3 \mathrm{~m}$, width of $10 \mathrm{~cm}$, and height of $20 \mathrm{~cm}$}

Test scores in this exercise averaged 14.80, where boys (14.47) were slightly lower than girls (15.13). The value of girls is also relatively more homogeneous. After given local culture-based gymnastics exercises, significant progress was seen with the acquisition of an average value of 36.10 . Boys become 36.27 and girls become 35.93. The progress of the child is clearly seen, because the lowest score achieved is (43) from before being given training (23).

\section{f. Throw a tennis ball into the basket with a distance of 2 meters}

For this type of practice, the results of the assessment of Pertiwi Kindergarten children were the lowest, either before the local culture-based exercise training was conducted or after the activity was given. Before given gymnastics, the overall average value of 6.50 . The results obtained by boys are better (7.27) than girls (5.73). After the children are given local culture-based gymnastics training, the response in throwing the ball is better. This can be seen from the average value (8.53) which increased significantly. More significant changes were seen in girls with an average acquisition of 8.93 while boys 8.13 . Likewise, the previous lowest response was only 4 points, after being given gymnastics the value jumped to 12 .

\section{g. Motoric Perceptual Ability Score}

Of the six types of tests carried out, in general local culture-based exercises given to Pertiwi Kindergarten students have a different effect. This is evident from the overall average value or score of motoric ability ie (101.10) after gymnastics is given to be (168.43) than the value before the training was given. This condition occurs in both male and female students. The motoric abilities of students after being given local culture-based exercises apply to both students with the lowest scores and with the highest scores. After the training is given, student scores increase before being given gymnastics training. Likewise with the lowest response previously only worth 132 points, after being given gymnastics exercises the value jumped to 206.

\subsection{Normality Test}

This test is intended to find out that the sample comes from normally distributed objects. The calculation of this normality test uses the Kolmogorov-Smirnov formula with data processing using SPSS 16 computer program at the significance level $\alpha=0.05$.

Table 4. Normality Test of Motoric Perceptual Ability Test

Tests of Normality

\begin{tabular}{|l|r|r|r|l|l|}
\hline & \multicolumn{6}{|c|}{ Kolmogorov-Smirnov ${ }^{\mathrm{a}}$} & & \\
\cline { 2 - 6 } & Statistic & \multicolumn{1}{c|}{ Df } & \multicolumn{1}{c|}{ Sig. } & Conclusion & Information \\
\hline TS1A & .126 & 30 & $.200^{*}$ & Accepted Ho & Normal \\
TS1B & .136 & 30 & .168 & Accepted Ho & Normal \\
TS1C & .139 & 30 & .144 & Accepted Ho & Normal \\
TS1D & .119 & 30 & $.200^{*}$ & Accepted Ho & Normal \\
TS1E & .121 & 30 & $.200^{*}$ & Accepted Ho & Normal \\
\hline
\end{tabular}




\begin{tabular}{|l|l|l|l|l|l|} 
TS1F & .108 & 30 & $.200^{*}$ & Accepted Ho & Normal \\
SKPM1 & .155 & 30 & .063 & Accepted Ho & Normal \\
TS2A & .127 & 30 & $.200^{*}$ & Accepted Ho & Normal \\
TS2B & .128 & 30 & $.200^{*}$ & Accepted Ho & Normal \\
TS2C & .080 & 30 & $.200^{*}$ & Accepted Ho & Normal \\
TS2D & .104 & 30 & $.200^{*}$ & Accepted Ho & Normal \\
TS2E & .131 & 30 & .198 & Accepted Ho & Normal \\
TS2F & .147 & 30 & .099 & Accepted Ho & Normal \\
SKPM2 & .102 & 30 & $.200^{*}$ & Accepted Ho & Normal \\
\hline
\end{tabular}

a. Lilliefors Significance Correction

*. This is a lower bound of the true significance.

Based on Table 4 above, shows the results of the motoric perceptual ability test on students of Pertiwi Banda Aceh Kindergarten showing Sig. > 0.05. Thus it can be concluded that the population of motoric perceptual ability test scores are normally distributed and feasible to be treated using the $\mathrm{t}$ test.

\subsection{Homogeneity Test}

Homogeneity calculation is useful for testing the sameness of a sample that is uniform or not the sample variance taken from the population. Testing homogeneity by using t test of homogeneity of variance in SPSS 16. Then from the output data it is seen the probability value, if the probability value $>0.05$ makadata comes from populations that have the same variant. If the probability value is $<0.05$ then the data coming from the population is not homogeneous. The results of the analysis can be seen below:

Table 5. Homogeneity Test of Motoric Perceptual Ability Test of Homogeneity of Variances

\begin{tabular}{|l|r|r|r|r|l|l|}
\hline & $\begin{array}{c}\text { Levene } \\
\text { Statistic }\end{array}$ & df1 & df2 & Sig. & Conclusion & Information \\
\hline TS1A & .020 & 1 & 28 & .889 & Accepted Ho & Homogeneity \\
TS1B & .032 & 1 & 28 & .860 & Accepted Ho & Homogeneity \\
TS1C & 1.671 & 1 & 28 & .207 & Accepted Ho & Homogeneity \\
TS1D & 2.040 & 1 & 28 & .164 & Accepted Ho & Homogeneity \\
TS1E & .670 & 1 & 28 & .420 & Accepted Ho & Homogeneity \\
TS1F & 3.498 & 1 & 28 & .072 & Accepted Ho & Homogeneity \\
SKPM1 & .355 & 1 & 28 & .556 & Accepted Ho & Homogeneity \\
TS2A & .626 & 1 & 28 & .435 & Accepted Ho & Homogeneity \\
TS2B & .018 & 1 & 28 & .894 & Accepted Ho & Homogeneity \\
TS2C & 2.099 & 1 & 28 & .158 & Accepted Ho & Homogeneity \\
TS2D & .031 & 1 & 28 & .861 & Accepted Ho & Homogeneity \\
TS2E & .176 & 1 & 28 & .678 & Accepted Ho & Homogeneity \\
TS2F & .900 & 1 & 28 & .351 & Accepted Ho & Homogeneity \\
SKPM2 & 1.581 & 1 & 28 & .219 & Accepted Ho & Homogeneity \\
\hline
\end{tabular}




\section{Source: Research Results}

Based on the statistical analysis of the homogeneity test that has been done, the probability value is $>0.05$, so it can be concluded that the data come from populations that have the same or homogeneous variance. That is, the data is feasible to be processed using the $t$ test.

\subsection{T-test: Impact of Implementation of Gymnastics Based on Local Culture}

The hypothesis in this study is that it is suspected that there is an impact of the implementation of local culture-based exercises on the motorized perceptual abilities of early childhood in kindergarten TK Aceh.

Criteria I of decision making, namely the calculation of $t$ count is less than the table score, with a significant level $>0.05$, there is no significant difference in the value of the motoric perceptual ability test between pre-test and post-test. Criterion II, the calculation of $t$ count is greater than $\mathrm{t}$ table, with a significant level $<0.05$, then there is a significant difference in the value of the motoric perceptual ability test between pre-test and post-test. Based on the analysis of test data used to answer the above hypothesis is the t-test of 2 samples. The following results of the t test analysis:

Table 6. Test Difference in Average Pre-test and Post-test scores

\begin{tabular}{|c|c|c|c|c|c|c|c|c|}
\hline & \multicolumn{8}{|c|}{ Paired Samples Test } \\
\hline & \multicolumn{5}{|c|}{ Paired Differences } & \multirow[b]{3}{*}{$\mathrm{t}$} & \multirow[b]{3}{*}{$\mathrm{df}$} & \multirow{3}{*}{$\begin{array}{l}\text { Sig. (2- } \\
\text { tailed) }\end{array}$} \\
\hline & \multirow[b]{2}{*}{ Mean } & \multirow{2}{*}{$\begin{array}{c}\text { Std. } \\
\text { Deviation }\end{array}$} & \multirow[b]{2}{*}{ Std. Error Mean } & \multicolumn{2}{|c|}{$\begin{array}{c}95 \% \text { Confidence } \\
\text { Interval of the } \\
\text { Difference }\end{array}$} & & & \\
\hline & & & & Lower & Upper & & & \\
\hline TS1A - TS2A & -14.933 & 12.312 & 2.248 & -19.531 & -10.336 & -6.643 & 29 & .000 \\
\hline TS1B - TS2B & -22.833 & 6.581 & 1.202 & -25.291 & -20.376 & -19.002 & 29 & .000 \\
\hline TS1C - TS2C & -3.233 & 2.315 & .423 & -4.098 & -2.369 & -7.651 & 29 & .000 \\
\hline TS1D - TS2D & -3.000 & 1.800 & .329 & -3.672 & -2.328 & -9.127 & 29 & .000 \\
\hline TS1E - TS2E & -21.300 & 7.149 & 1.305 & -23.970 & -18.630 & -16.318 & 29 & .000 \\
\hline TS1F - TS2F & -2.033 & 3.557 & .649 & -3.362 & -.705 & -3.131 & 29 & .004 \\
\hline $\begin{array}{l}\text { SKPM1 - } \\
\text { SKPM2 }\end{array}$ & -67.333 & 19.983 & 3.648 & -74.795 & -59.871 & -18.455 & 29 & .000 \\
\hline
\end{tabular}

Based on the statistical analysis of the t test that has been carried out, obtained Sig. (2tailed) $>0.05$, it can be concluded that Ho is accepted and there is a significant influence on local culture-based exercise on the motorized perceptual ability of early childhood in kindergarten TK Aceh. Following is the explanation of the test results $t$ :

\subsection{Discussion}

The initial ability of students before conducting treatment in the form of motoric perceptual ability tests shows the pre-test mean value (101.10). While the results of the posttest mean scores after being given local culture-based gymnastic treatments become (168.43). From the results of the average value of local culture-based exercise gives a significant effect 
on perceptual motoric ability as according to Agus Mahendra (2000: 14) children involved in gymnastics will develop muscular endurance, strength, power, flexibility, coordination, agility, and balance.

From the results of the data analysis conducted above, it is clear that in providing local culture-based exercises can affect the perceptual motoric ability of early childhood in Pertiwi Kindergarten, Banda Aceh as the results of the $t$ test to answer hypotheses with $t$ count score $(18.455)>t$ table $(2.045)$ where Ha is accepted while Ho is rejected.

This was stated by Samsuddin (2008: 22), that the stimulation of physical activity accompanied by music would have an influence on the development of gross motoric ability combined with swinging hands and feet both using tools and without using tools.

\section{Conclusion}

Based on the results of data analysis obtained t count (18.455)> t table (2.045), thus it can be concluded that there is a significant influence between local culture-based exercise on the motoric perceptual ability of early childhood in Pertiwi Kindergarten, Banda Aceh.

\section{References}

Amelia, L., et al. (2019). Analysis of the Use of Kindergarten Watching Siaga Bencana Learning Model for Structured Positive Thinking Ability on Early Childhood. Budapest International Research and Critics Institute (BIRCI-Journal) : Humanities and Social Sciences, 379-387.

Ananda, R. (2019). Evaluation of Learning Outcome: Comparative Education Unit Level Curriculum with the 2013 Curriculum in MTsN 1 Medan. Britain International of Humanties and Social Sciences (BIoHS) Journal, 74-80.

Louk, M. J. H., \& Sukoco, P. (2016). Pengembangan media audio visual dalam pembelajaran keterampilan motorik kasar pada anak tunagrahita ringan. Jurnal Keolahragaan. https://doi.org/10.21831/jk.v4i1.8132

Reshi Yufitsa, Anizar Ahmad, J. E. (2016). Implementasi Permainan Tradisional Aceh Di Paud It Al-Fatih Banda Aceh. Jurnal Ilmiah Mahasiswa Pendidikan Anak Usia Dini.

Sulasmi, I., Dewi. S, A. C., \& Karmila, M. (2019). Analisis perilaku hidup bersih dan sehat(phbs) terhadap kemampuan motorik anak usia dini di pos paud al masyithoh Plamongansari. Paudia: Jurnal Penelitian Dalam Bidang Pendidikan Anak Usia Dini. https://doi.org/10.26877/paudia.v7i2.3271

Sumarsono, A., \& Wasa, C. (2019). Pengembangan Senam Kebugaran " Kitorang Bersatu" Pada Suku Marind Papua. Jendela Olahraga. https://doi.org/10.26877/jo.v4i1.2417

Bemawa, H. H. (2010). Implementasi Sekolah Adiwiyata Berbasis Kearifan Lokal. Meneguhkan Peran Penelitian Dan Pengabdian Kepada Masyarakat Dalam Memuliakan Martabat Manusia.

Brontowiyono, W., Lupiyanto, R., \& Wijaya, D. (2010). Pengelolaan Kawasan Sungai Code Berbasis Masyarakat. Jurnal Sains \&Teknologi Lingkungan. https://doi.org/10.20885/jstl.vol2.iss1.art2

Hakim, O. O. A. A., \& Purnama, B. E. (2012). Perancangan dan Implementasi Sistem Pembelajaran Aksara Jawa untuk SD Berbasis Multimedia Di SDN Bumirejo 02. Speed - Sentra Penelitian Engineering Dan Edukasi. https://doi.org/10.3112/SPEED.V4I2.923

Hasani, Q. (2012). Konservasi Sumberdaya Perikanan Berbasis Masyarakat, Implementasi Nilai Luhur Budaya Indonesia Dalam Pengelolaan Sumberdaya Alam. Aquasains. 
Holilah, M. (2016). Kearifan Ekologis Budaya Lokal Masyarakat Adat Cigugur Sebagai Sumber Belajar Ips. Jurnal Pendidikan Ilmu Sosial. https://doi.org/10.17509/jpis.v24i2.1453

Irawan, A., \& Kencanawaty, G. (2017). Implementasi Pembelajaran Matematika Realistik Berbasis Etnomatematika. Journal of Medives.

Junaidi, F., Andhira, R., Mustopa, E., S-, M., \& Belakang, L. (2017). Implementasi pembelajaran bipa berbasis budaya sebagai strategi menghadapi mea. The 1st Education and Language International Conference.

Jupir, M. M. (2013). Implementasi Kebijakan Pariwisata Berbasis Kearifan Lokal. Of Indonesian Tourism and Development Studies.

Jupir, M. M. (2013). Implementasi Kebijakan Pariwisata Berbasis Kearifan Lokal (Studi di Kabupaten Manggarai Barat). Journal of Indonesian Tourism and Development Studies. https://doi.org/10.21776/ub.jitode.2013.001.01.05

Kebutuhan Pelatihan Manajemen Pembelajaran Seni Tari Berbasis Pendekatan Saintifik Pada Guru Sekolah Dasar. (2014). Catharsis: Journal of Arts Education.

Mony, A. (2017). Pengembangan Nelayan Berbasis Kearifan Lokal: Sebuah Pendekatan Socio-Legal Analysis. Risalah Kebijakan Pertanian Dan Lingkungan: Rumusan Kajian Strategis Bidang Pertanian Dan Lingkungan. https://doi.org/10.20957/jkebijakan.v3i3.16254

Muhaimin, M. (2015). Implementasi Model Pembelajaran Berbasis Masalah Lokal Dalam Mengembangkan Kompetensi Ekologis Pada Pembelajaran Ips. Sosio Didaktika: Social Science Education Journal. https://doi.org/10.15408/sd.v2i1.1409

Murtadho, A. (2016). Arah Pengembangan Kajian Ekonomi Islam Berbasis Kesatuan Ilmu Pengetahuan Di Iain Walisongo. Economica: Jurnal Ekonomi Islam. https://doi.org/10.21580/economica.2014.5.1.761

Muzakki, M., \& Fauziah, P. Y. (2015). Implementasi pembelajaran anak usia dini berbasis budaya lokal di PAUD full day school. Jurnal Pendidikan Dan Pemberdayaan Masyarakat. https://doi.org/10.21831/jppm.v2i1.4842

Pembangunan, J., Fondasi, P.:, Implementasi, A., Pendidikan, P., Kontekstual, M., \& Amirin, T. M. (2012). Implementasi Pendekatan Pendidikan Multikultural Kontekstual Berbasis Kearifan Lokal Di Indonesia Contextual Implementation Of Multicultural Education Approach Based On Local Wisdom In Indonesia. Journal.Uny.Ac.Id.

Pendidikan, J., \& Masyarakat, D. P. (2015). Penerbit Ikatan Akademisi Pendidikan Nonformal Dan Informal Indonesia (Ikapenfi) Bekerja Sama Dengan Program Studi S2 Pendidikan Luar Sekolah Program Pascasarjana Universitas Negeri Yogyakarta. JPPM.

Prihastari, E. B. (2015). Pemanfaatan Etnomatematika Melalui Permainan Engklek Sebagai Sumber Belajar. Mendidik.

Rahmah, S., Yusnizar, and Rahayu, T. (2019). Packaging Audio Visual Media in Tatak Tintoa Serserin Learning of Dairi Dance. Britain International of Linguistics, Arts and Education (BIoLAE) Journal, 153-159.

Sardjiyo, S., \& Pannen, P. (2005). Pembelajaran Berbasis Budaya: Model Inovasi Pembelajaran dan Implementasi Kurikulum Berbasis Kompetensi. Jurnal Pendidikan.

Supandi, K., W., \& A., L. (2015). Keefektifan Pembelajaran Blended Learning Berbasis Kearifan Lokal pada Pembelajaran Matematika. Jurnal Pendidikan Dan Pembelajaran.

Tisngati, U. (2015). Pembelajaran Matematika Berbasis Kearifan Lokal Menggunakan Model Akik. In Inovasi Pembelajaran untuk Pendidikan Berkemajuan.

Triwardani, R., \& Rochayanti, C. (2014). Implementasi Kebijakan Desa Budaya dalam Upaya Pelestarian Budaya Lokal. Reformasi. 
Tyas Catur Pramudi, Y., \& Budiman, F. (2010). Desain Virtual Gamelan Jawa Sebagai Media Pembelajaran. Seminar Nasional Aplikasi Teknologi Informasi.

Wagiran, \& Ruwanto, B. (2016). Implementasi sekolah adiwiyata berbasis kearifan lokal mahemayu hayuning bawana. In Prosiding Seminar Nasional.

Yunian Putra, R. W., \& Indriani, P. (2017). Implementasi Etnomatematika Berbasis Budaya Lokal dalam Pembelajaran Matematika pada Jenjang Sekolah Dasar. NUMERICAL (Jurnal Matematika Dan Pendidikan Matematika). https://doi.org/10.25217/numerical.v1i1.118

Sumarsono, A., \& Wasa, C. (2019). Pengembangan Senam Kebugaran “ Kitorang Bersatu” Pada Suku Marind Papua. Jendela Olahraga. https://doi.org/10.26877/jo.v4i1.2417 